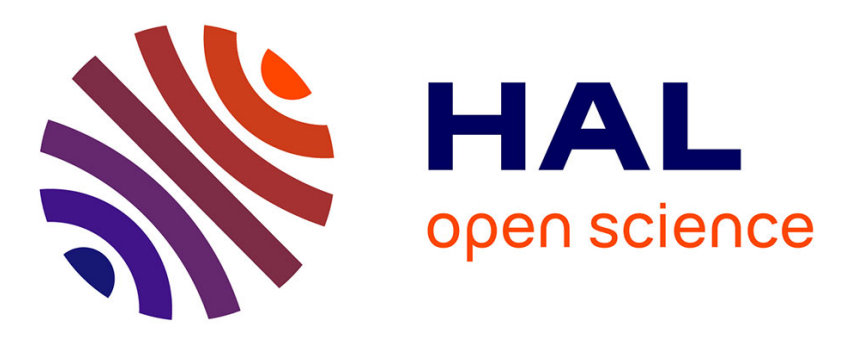

\title{
Efficient Broadly Tunable Waveguide Lasers in Yb3+:CaF2 Produced by Deep Diamond Saw Dicing
}

Pavel Loiko, Ludovic Gauthier-Manuel, Gurvan Brasse, Alain Braud, Abdelmjid Benayad, Patrice Camy

\section{- To cite this version:}

Pavel Loiko, Ludovic Gauthier-Manuel, Gurvan Brasse, Alain Braud, Abdelmjid Benayad, et al.. Efficient Broadly Tunable Waveguide Lasers in Yb3+:CaF2 Produced by Deep Diamond Saw Dicing. CLEO: Applications and Technology, 2021, San Jose, United States. pp.JTu3A.26, 10.1364/CLEO_AT.2021.JTu3A.26. hal-03368749

\section{HAL Id: hal-03368749 \\ https://hal.science/hal-03368749}

Submitted on 7 Oct 2021

HAL is a multi-disciplinary open access archive for the deposit and dissemination of scientific research documents, whether they are published or not. The documents may come from teaching and research institutions in France or abroad, or from public or private research centers.
L'archive ouverte pluridisciplinaire HAL, est destinée au dépôt et à la diffusion de documents scientifiques de niveau recherche, publiés ou non, émanant des établissements d'enseignement et de recherche français ou étrangers, des laboratoires publics ou privés. 


\title{
Efficient Broadly Tunable Waveguide Lasers in $\mathbf{Y b}^{3+}: \mathrm{CaF}_{2}$ Produced by Deep Diamond Saw Dicing
}

\author{
Pavel Loiko, ${ }^{1, *}$ Ludovic Gauthier-Manuel, ${ }^{2}$ Gurvan Brasse, ${ }^{1}$ Alain Braud, ${ }^{1}$ Abdelmjid Benayad, ${ }^{1}$ \\ and Patrice Camy ${ }^{1}$ \\ ${ }^{I}$ Centre de recherche sur les Ions, les Matériaux et la Photonique (CIMAP), UMR 6252 CEA-CNRS-ENSICAEN, Université de Caen Normandie, \\ 6 Boulevard du Maréchal Juin, 14050 Caen Cedex 4, France \\ ${ }^{2}$ FEMTO-ST Institute, $15 B$ avenue des Montboucons, 25030 Besançon Cedex, France \\ *pavel.loiko@ensicaen.fr
}

\begin{abstract}
High-aspect-ratio ridge waveguides (propagation losses: $0.13 \pm 0.05 \mathrm{~dB} / \mathrm{cm}$ ) were fabricated in $\mathrm{Yb}^{3+}: \mathrm{CaF}_{2}$ by diamond-saw-dicing. The waveguide laser generated $723 \mathrm{~mW}$ at $1029-1051 \mathrm{~nm}$ with a slope efficiency of $76.0 \%$; wavelength tuning between $1009-1072 \mathrm{~nm}$ was achieved. (C) 2020 The Author(s)
\end{abstract}

Ytterbium $\left(\mathrm{Yb}^{3+}\right)$ doped calcium fluoride $\left(\mathrm{CaF}_{2}\right)$ is an attractive laser material [1]. The host matrix provides high thermal conductivity $\left(\sim 9.7 \mathrm{Wm}^{-1} \mathrm{~K}^{-1}\right)$, isotropic thermal expansion, negative thermal lensing and low refractive index $(n=1.429$ at $\sim 1 \mu \mathrm{m}$ ). $\mathrm{CaF}_{2}$ can be easily doped with $\mathrm{Yb}^{3+}$ and it features strong ion clustering already at low doping levels (above 0.1 at.\%) resulting in significant inhomogeneous broadening of spectral bands (a glassy-like spectroscopic behavior) [2]. The smooth and broad gain spectra of $\mathrm{Yb}^{3+}: \mathrm{CaF}_{2}$ determine its potential for broadband wavelength tuning and especially generation of femtosecond pulses in mode-locked oscillators at $\sim 1 \mu \mathrm{m}$ [1].

So far, little attention was paid to the development of $\mathrm{Yb}^{3+}: \mathrm{CaF}_{2}$ waveguide (WG) lasers [3,4]. Ren et al. fabricated buried channel WGs in $\mathrm{Yb}^{3+}, \mathrm{Na}^{+}: \mathrm{CaF}_{2}$ by ultrafast laser inscription and achieved $174 \mathrm{~mW}$ at $\sim 1.01 \mu \mathrm{m}$ with an opticalto-optical efficiency of $45.3 \%$ [4]. In the present work, we report on highly-efficient and wavelength-tunable WG lasers fabricated using diamond saw dicing [5] of bulk $\mathrm{Yb}^{3+}: \mathrm{CaF}_{2}$ crystals.

High aspect ratio (height: $200 \mu \mathrm{m}$, width: 10-50 $\mu \mathrm{m}$ ) surface channel (ridge) WGs were produced in a bulk 4.5 at.\% $\mathrm{Yb}^{3+}: \mathrm{CaF}_{2}$ crystal by "deep" diamond saw dicing, Fig. 1(a). The guides exhibited no chipping at the facets nor cracks, as well as good verticality of the side walls. The r.m.s. surface roughness of the latter studied using a confocal microscope in an interferometric mode was $0.5 \mathrm{~nm}$, Fig. 1(b). The WG propagation loss $\delta$ loss increased for narrower guides, from $0.17 \mathrm{~dB} / \mathrm{cm}$ for the $50 \mu \mathrm{m}$ wide guide up to $0.52 \mathrm{~dB} / \mathrm{cm}$ for the $10 \mu \mathrm{m}$ wide one (for vertical polarization, at $0.91 \mu \mathrm{m}$ ).

The laser operation was studied in the continuous-wave $(\mathrm{CW})$ regime using a plano-plano cavity. It was formed by a pump mirror (PM) coated for HT at $0.88-0.99 \mu \mathrm{m}$ and for HR at 1.02-1.20 $\mu \mathrm{m}$, and a set of output couplers (OCs) having a transmission $T_{\mathrm{OC}}$ in the range of $2 \%-50 \%$ at 1.0-1.1 $\mu \mathrm{m}$. The $\mathrm{Yb}^{3+}: \mathrm{CaF}_{2}$ sample containing the WGs was mounted on a Cu-holder and it was passively cooled. As a pump source, we employed a CW Ti:Sapphire laser emitting at $979.5 \mathrm{~nm}$ in the fundamental mode $\left(\mathrm{M}^{2} \approx 1\right)$ with linear polarization (vertical). Its output was focused using a spherical $\mathrm{CaF}_{2}$ lens (f $=40 \mathrm{~mm}$ ). For the $40 \mu \mathrm{m}$ wide WG, the pump coupling efficiency $\eta_{\text {coupl }}$ was $74.2 \%$. With increasing the output coupling, the pump absorption under lasing conditions $\eta_{\mathrm{abs}, \mathrm{L}}$ decreased from $92.7 \%\left(T_{\mathrm{OC}}=1 \%\right)$ to $68.2 \%\left(T_{\mathrm{OC}}=50 \%\right)$.
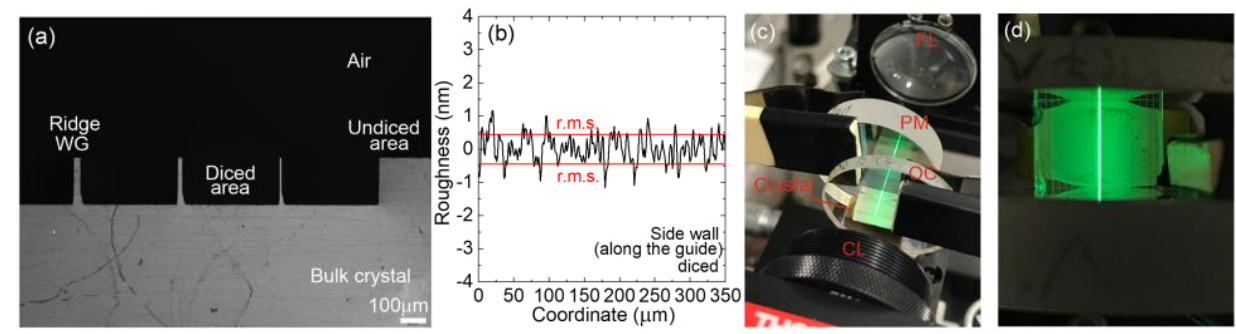

Fig. 1. (a) Confocal laser microscopy image of an end-facet of a 4.5 at. $\% \mathrm{Yb}^{3+}: \mathrm{CaF}_{2}$ sample containing ridge waveguides, bright field, reflection mode, $\lambda=405 \mathrm{~nm}$; (b) roughness profile for one of the WG side walls (diced); (c) photograph of the waveguide laser: PM - pump mirror, OC - output coupler, FL and CL - focusing and collimating lenses, respectively; (d) top view photograph of the pumped guide.

The laser performance of the $40 \mu \mathrm{m}$ wide guide for the pump wavelength of $979.5 \mathrm{~nm}$ corresponding to the zerophonon-line of $\mathrm{Yb}^{3+}$ ions in $\mathrm{CaF}_{2}$ is shown in Fig. 2(a,b). The laser generated a maximum output power of $723 \mathrm{~mW}$ at $1029-1051 \mathrm{~nm}$ with a slope efficiency $\eta$ of $76.0 \%$ ( $v s$. the absorbed pump power) and a laser threshold of $165 \mathrm{~mW}$ (for $\left.T_{\mathrm{OC}}=20 \%\right)$. The maximum optical-to-optical efficiency $v s$. the pump power incident on the crystal $\eta_{\text {opt }}$ was $38.9 \%$. With increasing the output coupling, the laser threshold gradually increased, from $52 \mathrm{~mW}\left(T_{\mathrm{OC}}=1 \%\right)$ to $394 \mathrm{~mW}$ ( $T_{\mathrm{OC}}$ 
$=50 \%)$. No lasing was achieved when pumping into the bulk area of the sample. With increasing the output coupling, the central emission wavelength experienced a slight blue-shift, from $\sim 1048 \mathrm{~nm}\left(T_{\mathrm{OC}}=1 \%\right)$ to $\sim 1029 \mathrm{~nm}\left(T_{\mathrm{OC}}=50 \%\right)$, Fig. 2(a). The observed laser efficiencies were analyzed using the Caird approach, i.e., with the formula $1 / \eta=1 / \eta_{0}(1+$ $\left.2 \gamma / \gamma_{\mathrm{OC}}\right)$ where $\gamma$ is the loss coefficient and $\gamma_{\mathrm{OC}}$ is the output-coupling loss, yielding the intrinsic slope efficiency $\eta_{0}$ of $75.0 \pm 4 \%$ and $\delta_{\text {loss }}$ of $0.13 \pm 0.05 \mathrm{~dB} / \mathrm{cm}$, Fig. 2(c). The laser mode was localized near the top part of the guide and it was elliptical, Fig. 2(d). The measured beam quality factors were $\mathrm{M}^{2}{ }_{\mathrm{x}}=1.05 \pm 0.05$ and $\mathrm{M}^{2} \mathrm{y}=1.3 \pm 0.1$.
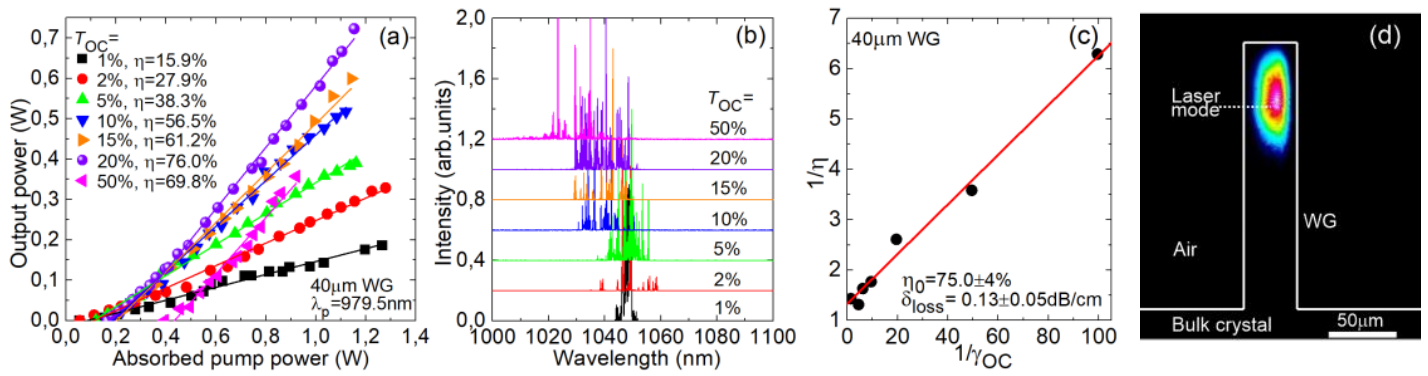

Fig. 2. Laser performance of the deep-diced $\mathrm{Yb}^{3+}: \mathrm{CaF}_{2}$ waveguide (width: $40 \mu \mathrm{m}$ ): (a) input-output dependences, $\eta$ - slope efficiency; (b) typical spectra of laser emission measured at maximum $P_{\text {abs; }}$; (c) Caird analysis of propagation losses; (d) near-field profile of the laser mode, $T_{\mathrm{OC}}=20 \%, P_{\mathrm{abs}} \sim 0.5 \mathrm{~W}$. Pump polarization: vertical, $\lambda_{\mathrm{p}}=979.5 \mathrm{~nm}$. In (c), white lines mark the air $/$ crystal interfaces.

To demonstrate wavelength tuning of the $\mathrm{Yb}^{3+}: \mathrm{CaF}_{2}$ WG laser, the flat $\mathrm{OC}$ was replaced by a concave one $(\mathrm{RoC}=-$ $100 \mathrm{~mm}$ ) with $T_{\mathrm{OC}}=2 \%$ resulting in a nearly hemispherical cavity. As a tuning element, we used an uncoated quartz birefringent plate with the optical axis lying in the plane of the plate. It was placed at the Brewster angle near the output facet of the sample. A continuous wavelength tuning between 1009.2 and $1072.4 \mathrm{~nm}$ was demonstrated, Fig. 3. This corresponded to a tuning range of $\sim 63 \mathrm{~nm}$. The maximum of the tuning curve was observed at $\sim 1052 \mathrm{~nm}$ corresponding to an output power of $118 \mathrm{~mW}$.
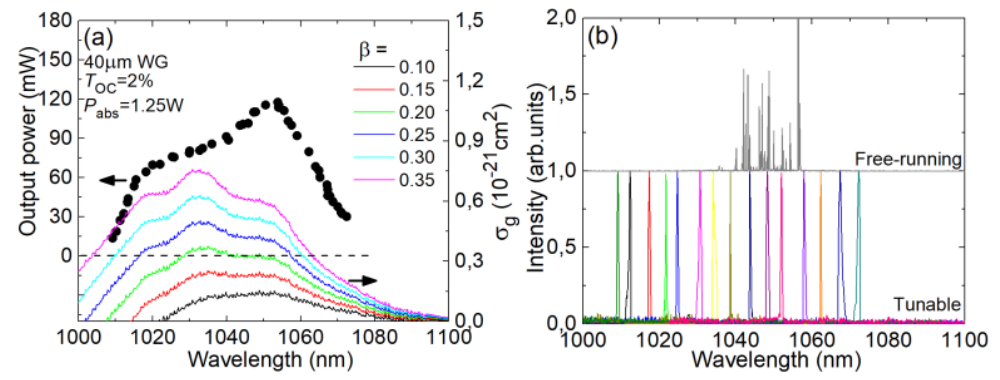

Fig. 3. Tunable deep-diced $\mathrm{Yb}^{3+}: \mathrm{CaF}_{2}$ ridge waveguide laser (WG width: $40 \mu \mathrm{m}$ ): (a) tunability curve, $T_{\mathrm{OC}}=2 \%, P_{\mathrm{abs}}=1.25 \mathrm{~W}$, the gain cross-section, $\sigma_{\mathrm{g}}$, spectra for several inversion ratios $\beta=N_{2}\left({ }^{2} \mathrm{~F}_{5 / 2}\right) / N_{\mathrm{Yb}}$ are shown for comparison; (b) typical spectra of laser emission from the tunable laser; the spectrum for the free-running laser is shown for comparison.

To conclude, deep diamond saw dicing is a powerful approach to fabricate ridge WGs in bulk $\mathrm{Yb}^{3+}: \mathrm{CaF}_{2}$ crystals. Such guides ensure low propagation losses (down to $0.13 \pm 0.05 \mathrm{~dB} / \mathrm{cm}$ at $\sim 1 \mu \mathrm{m}$ ), small surface roughness and good verticality of the side walls and the lack of cracking / chipping. No post-processing polishing is required for the ridges. The combination of good thermal properties of $\mathrm{CaF}_{2}$ with the broadband emission of $\mathrm{Yb}^{3+}$ ions determine the power scaling capabilities of deep-diced $\mathrm{Yb}^{3+}: \mathrm{CaF}_{2}$ WG lasers, as well as the broadband wavelength tuning. The fabricated guides are promising for compact mode-locked oscillators at $\sim 1 \mu \mathrm{m}$ operating at high repetition rates (GHz-range).

\section{References}

[1] F. Druon, S. Ricaud, D. N. Papadopoulos, A. Pellegrina, P. Camy, J. L. Doualan, R. Moncorgé, A. Courjaud, E. Mottay, and P. Georges, "On $\mathrm{Yb}: \mathrm{CaF}_{2}$ and $\mathrm{Yb}: \mathrm{SrF}_{2}$ : review of spectroscopic and thermal properties and their impact on femtosecond and high power laser performance," Opt. Mater. Express 1(3), 489-502 (2011).

[2] V. Petit, P. Camy, J-L. Doualan, X. Portier, and R. Moncorgé, "Spectroscopy of $\mathrm{Yb}^{3+}: \mathrm{CaF}_{2}$ : From isolated centers to clusters," Phys. Rev. B 78(8), 085131-1-12 (2008).

[3] P. Loiko, R. Soulard, E. Kifle, L. Guillemot, G. Brasse, A. Benayad, J.-L. Doualan, A. Braud, M. Aguiló, F. Díaz, X. Mateos, and P. Camy, "Ytterbium calcium fluoride waveguide laser," Opt. Express 27(9), 12647-12658 (2019).

[4] Y. Ren, C. Cheng, Y. Jia, Y. Jiao, D. Li, M. D. Mackenzie, A. K. Kar, and F. Chen, "Switchable single-dual-wavelength Yb,Na:CaF 2 waveguide lasers operating in continuous-wave and pulsed regimes," Opt. Mater. Express 8(6), 1633-1641 (2018).

[5] P. Loiko, R. Soulard, G. Brasse, J.-L. Doualan, B. Guichardaz, A. Braud, A. Tyazhev, A. Hideur, and P. Camy, "Watt-level Tm:LiYF4 channel waveguide laser produced by diamond saw dicing," Opt. Express 26(19), 24653-24662 (2018). 